\title{
Prevalence of interspecific competition in a mixed poplar/black locust plantation under adverse climate conditions
}

\author{
Nicolas Marron ${ }^{1}$ (D) $\cdot$ Pierrick Priault ${ }^{1} \cdot$ Cécilia Gana $^{1} \cdot$ Dominique Gérant $^{1} \cdot$ Daniel Epron $^{1}$
}

Received: 15 November 2017 / Accepted: 29 January 2018 / Published online: 27 February 2018

(C) INRA and Springer-Verlag France SAS, part of Springer Nature 2018

\begin{abstract}
- Key message In a mixed poplar/black locust plantation in central France, adverse conditions have led to a prevalence of interspecific competition, resulting in a poorer performance than monocultures.

- Context In mixed tree plantations, the presence of woody $\mathrm{N}_{2}$-fixing species is thought to reduce $\mathrm{N}$ needs by fertilization. However, benefits associated to soil nitrogen enrichment have to outweigh the negative effects of interspecific competition. To do so, co-occurring tree species have to be chosen carefully to promote niche sharing between species and reduce competition. Black locust and poplar mixtures therefore seem promising since both species are fast growing and have potentially complementary crown shapes.

- Aims Our objective was to evaluate the impact of the poplar/black locust mixture on the growth, above- and belowground biomass production, and nitrogen allocation of the two species, as compared to their respective monocultures.

- Methods An experimental plantation mixing poplar and black locust was set up in central France. For five growing seasons, growth, nitrogen allocation, and carbon allocation were monitored for the two species growing either in mixture or in monoculture.

- Results After a couple of promising growing seasons, black locust growth and survival slowly declined, mainly in the mixture. At the stand level, biomass production in the mixed plots was nearly $50 \%$ below the most productive monoculture (poplar) by age 5 years.

- Conclusion Under adverse conditions, interspecific competition in the mixture was the preponderant interaction, resulting in higher mortality and lower biomass production than the two monocultures.
\end{abstract}

Keywords $\mathrm{N}_{2}$ fixation - Biomass production and allocation · Interspecific interactions · Mixed-species woody plantation . Nitrogen dynamics

Handling Editor: Thomas Wohlgemuth

Contribution of the co-authors

Nicolas Marron: supervised the experiment by co-directing the Ph.D. of Cécilia Gana; contributed to data acquisition, analysis, and interpretation; and was the main writer.

Pierrick Priault: contributed to data acquisition, analysis, discussion, and writing.

Cécilia Gana: contributed to data acquisition and analysis within the framework of her Ph.D.

Dominique Gérant: contributed to data acquisition and analysis.

Daniel Epron: supervised the experiment by co-directing Cécilia Gana's

$\mathrm{Ph} . \mathrm{D}$. and contributed to data acquisition, analysis, discussion, and writing.

Nicolas Marron

nicolas.marron@inra.fr

1 Université de Lorraine, AgroParisTech, INRA, UMR 1434 Silva, 54000 Nancy, France

\section{Introduction}

Mixed species woody plantations associating nitrogen $(\mathrm{N})$ fixing and non-fixing species have the potential to increase biomass production and carbon sequestration, while providing other benefits including improved soil fertility and nutrient cycling and protection from pests and diseases (Forrester et al. 2005). Even if a decrease in production can be acceptable when it is compensated by a decrease in costs (fertilization, weeding, etc.), in most cases, mixtures are considered successful when aboveground biomass production is significantly higher in the mixture than in monocultures. Success is reached in the mixture when the positive interactions between species (i.e., facilitation through symbiotic $\mathrm{N}_{2}$ fixation, and/or reduced competition thanks to niche sharing resulting in more 
efficient resource utilization) outweigh the negative interactions (i.e., interspecific competition for uptake and use of resources) (Forrester et al. 2006a; Vandermeer 1989).

The mixture of $\mathrm{N}_{2}$-fixing/non-fixing species has already been the subject of much research in the southern hemisphere (Forrester et al. 2006a; Bouillet et al. 2013). Most common is the association of eucalypt not only with various species of acacia, but also with other $\mathrm{N}_{2}$-fixing species such as Falcataria moluccana (Falconer of the Moluccas; Austin et al. 1997), Leucaena leucocephala (False mimosa; Parrotta et al. 1996; Moraes de Jesus and Brouard 1989), or Casuarina equisetifolia (Filao; Parrotta et al. 1996). In the northern hemisphere, some studies were carried out in the 1970s and 1980s on the effect of the insertion of alder trees in association with various woody species. The beneficial effects of alder were observed on the growth of ash, liquidambar, tulip tree, spruce, pine, and Douglas-fir (Tarrant and Trappe 1971; Le Tacon et al. 1988). On the other hand, the fertilizing effect of alder associated with a fast-growing species such as poplar was less obvious: either no effect of $\mathrm{N}_{2}$ fixation by alder on poplar growth was visible at 3 years (Teissier du Cros et al. 1984) or alder strongly suffered from the competition with poplar (Le Tacon, unpublished results; Koupar et al. 2011). The effect of alder on Douglas-fir growth has also been shown to be either positive or negative depending on site conditions (Binkley 1983; Binkley et al. 1992).

Under temperate latitudes, black locust (Robinia pseudoacacia $\mathrm{L}$.) is an alternative to alder as the $\mathrm{N}_{2}$-fixing species in mixed plantations. However, in spite of its recognized potential in terms of biomass production and stress resistance, black locust has often been neglected in research and development programs, as has its response in associations with a non- $\mathrm{N}_{2}$-fixing species; this may be due to its invasive reputation or the thorns which make it difficult to manipulate (Grunewald et al. 2009; Mantovani et al. 2015). In addition to the possible benefits linked to $\mathrm{N}_{2}$ fixation, associating black locust with poplar (Populus spp.) also has the potential to improve resource utilization thanks to potentially complementary aboveground and belowground characteristics: the poplar canopy is often fastigiate with a single dominant stem, while the black locust canopy is stockier and much more ramified; both species have different surface root system architectures, with few ramifications in poplar and often a strongly ramified architecture in black locust (Drénou 2006). Such different traits could result in the two species exploring different layers above- and belowground and better sharing light, water, and nutrient resources when they are grown together, as compared to monocultures of each of the two species.

In the literature, comparative performances in mixtures and in corresponding monocultures varied drastically both among and within studies (Forrester et al. 2006a). For example, in the Binkley study (1983), associating red alder with Douglas-fir in 23-year-old plantations was twice as productive as the monoculture at a $\mathrm{N}$-poor site but growth was $15 \%$ inferior to the monoculture at a site where $\mathrm{N}$ was not limiting; this clearly shows the strong dependence of the results on the site conditions where the experiments are carried out. In the same way, Boyden et al. (2005) and Bouillet et al. (2013) showed that mixture effects in Eucalyptus/Falcataria and Eucalyptus/ Acacia plantations varied drastically as a function of soil richness in $\mathrm{N}$ and $\mathrm{P}$. Soil nutrient richness was indeed the main factor determining whether competition or facilitation was preponderant.

Forrester et al. (2005) attempted to draw a list of site factors and species attributes that are most likely to lead to increases in aboveground biomass production in mixtures when compared to monocultures. Notably, they stressed the importance of using species based on their height growth dynamics to ensure that neither species is suppressed by the other and that the less tolerant species is not overtopped by the more shade tolerant species. Poplar and black locust are both shadeintolerant species; however, as mentioned earlier, their different crown shapes should result in an optimized aboveground niche sharing between the species. Forrester et al. (2005) also suggested that mixtures should only be planted on sites where the processes and interactions between species will increase the availability of (through facilitative interactions) or reduce competition for (through competition reduction interactions) any major limiting resource for growth.

To study the interactions between poplar and black locust grown in a mixture compared with their respective monocultures, we set up an experimental instrumented plantation in central France and thoroughly studied it in terms of growth, biomass production, $\mathrm{N}$ allocation, and carbon allocation. The objectives of the present paper are (1) to describe the evolution of the mixture plantation in terms of growth, above- and belowground biomass production, and $\mathrm{N}$ allocation, as compared to the monocultures of the two species, and, because after five growing seasons (2011-2015), biomass production was much lower in the mixture plantation than in the monocultures, (2) to investigate possible reasons for the poor performances of the poplar/black locust association in this instance.

\section{Material and methods}

\subsection{Site characteristics}

The experimental site covers 0.7 ha at Saint-Cyr-en-Val (Loiret) in central France (Centre Val de Loire; 47 $48^{\prime}$ $\left.25.5^{\prime \prime} \mathrm{N} 1^{\circ} 58^{\prime} 36.1^{\prime \prime} \mathrm{E}\right)$. The site was previously an agricultural fallow for more than 15 years. The site, selected from a network of contrasted sites for poplar productivity, was known to have the lowest productivity (Bastien et al. 2015; Toillon et al. 2013). The plantation was established in 
February 2011 using 25-cm-long poplar woody stem cuttings and 1-year-old rooted black locust seedlings. No fertilization or irrigation was applied. Herbicide was spread once a year and mechanical weeding was done regularly. The plantation is composed of two blocks, each with three plots: one monoculture of poplar trees (Populus $\times$ euramericana, clone 'Dorskamp'), one monoculture of black locust trees (Robinia pseudoacacia, provenance 'Nyirseg'), and one mixed stand with alternating rows of the two species. The density of the plantation is 1428 trees $\mathrm{ha}^{-1}$ ( $2 \mathrm{~m}$ between trees and $3.5 \mathrm{~m}$ between rows).

\subsection{Monitoring soil and climate conditions}

Rainfall and air temperature were monitored from the establishment of the plantation with a rainfall gauge (ARG100, Campbell Scientific, Inc., Logan, UT, USA) and a thermistor (HMP45C probe, Campbell Scientific, Inc., Logan, UT, USA). One measurement was taken every $10 \mathrm{~s}$; sums (for rainfall) or averages (for temperature) were recorded every $30 \mathrm{~min}$.

Prior to planting, the composition of the upper soil layers was analyzed by collecting core samples at $0-15,15-30$, and $30-45 \mathrm{~cm}$ depths in each of the six plots. Soil texture and composition analyses were performed by the Soil Analysis Laboratory in Arras (US 10, LAS Arras, INRA Lille, France). Additionally, total $\mathrm{N}$ content was analyzed on soil samples collected at the same spots at $0-5,5-10,10-15$, $15-30,30-45$, and $45-60 \mathrm{~cm}$ depths, both prior to planting and 5 years after plantation. The soil is a Gleyic Luvisol (World Reference Base for Soil Resources classification) composed of approximately $70 \%$ sand, $20 \%$ loam, and $10 \%$ clay (Table 1).

Soil water content (SWC) was monitored continuously (one measurement every $5 \mathrm{~min}$ ) with water content reflectometers (CS615, Campbell Scientific, Inc., Logan, UT, USA) inserted $10 \mathrm{~cm}$ into the soil. Two reflectometers were used in each monoculture and four in the mixture; they were located either on the tree rows between two trees or between the rows on the diagonal between two trees. Meteorological and SWC data were recorded and stored on a data logger (CR3000, Campbell Scientific, Inc., Logan, UT, USA).

\subsection{Tree dimensions}

Tree growth was monitored every 3 weeks during the growing season (May to September) on 20 trees per species and treatment (20 trees in pure plots or 40 trees in mixed plots) in each block (160 trees in total). The trees to be monitored throughout the experiment were selected during the first growing season (2011), were representative of tree height distribution of the entire plantation, and were located in the central $7 \times 7$ trees of the plots, preserved from destructive measurements. Tree height or, for multi-stemmed trees, the height of the dominant
Table 1 Soil contents in clay, silt, sand, organic matter $(\mathrm{OM})$, organic carbon (OC), total nitrogen $(\mathrm{N}), \mathrm{C} / \mathrm{N}$, and $\mathrm{pH}$ at $0-15,15-30$, and 30 $45 \mathrm{~cm}$ depths prior to planting (February 2011). Means \pm standard errors, $n=6$

\begin{tabular}{lccc}
\hline & $0-15 \mathrm{~cm}$ & $15-30 \mathrm{~cm}$ & $30-45 \mathrm{~cm}$ \\
\hline Clay (\%) & $9 \pm 1$ & $9 \pm 2$ & $10 \pm 4$ \\
Silt (\%) & $23 \pm 2$ & $21 \pm 4$ & $21 \pm 6$ \\
Sand (\%) & $68 \pm 3$ & $70 \pm 6$ & $69 \pm 10$ \\
OM (\%) & $1.7 \pm 0.5$ & $1.5 \pm 0.4$ & $0.8 \pm 0.3$ \\
OC (\%) & $1.0 \pm 0.3$ & $0.9 \pm 0.2$ & $0.5 \pm 0.2$ \\
$\mathrm{~N}(\%)$ & $0.08 \pm 0.02$ & $0.07 \pm 0.02$ & $0.04 \pm 0.01$ \\
$\mathrm{C} / \mathrm{N}$ & $11.7 \pm 0.8$ & $11.6 \pm 0.6$ & $12.0 \pm 1.6$ \\
$\mathrm{pH}$ & $5.6 \pm 0.3$ & $6.0 \pm 0.5$ & $6.3 \pm 0.5$ \\
\hline
\end{tabular}

stem was measured. DBH (diameter at $1.30 \mathrm{~m}$ in height) was measured for all stems of the selected trees. For the multistemmed trees, a "virtual diameter" $(D v)$ was calculated from the sum of the section surfaces of each stem. In addition, these dimensions were measured for all trees in the plantation before each harvest and at the end of each growing season, in October. These measurements of all trees were used both (1) to select harvested trees covering the range of basal areas and (2) to extrapolate biomass data at plantation level using allometric relationships established from harvested trees (see below).

\subsection{Biomass}

Selected trees were harvested in June 2012 (month 17 after planting), June 2013 (month 28), June 2014 (month 40), and June 2015 (month 51). Eight trees per species and per treatment were harvested at each date. The root systems were excavated in the Voronoï polygon, corresponding to the elementary space defined by the half distances between the harvested tree stem and its neighbors (Levillain et al. 2011). We used a mini-shovel to dig out the stump and the coarse roots (diameter above $10 \mathrm{~mm}$ ); then, the medium and fine roots (5-10 $\mathrm{mm}$ and less than $5 \mathrm{~mm}$, respectively) were manually sorted. The different organs of the trees (branches, stem, roots and leaves) were separated and weighed (FW). Samples of each organ (about $10 \%)$ were weighed $\left(\mathrm{FW}_{\text {sample }}\right)$, dried at $65{ }^{\circ} \mathrm{C}$ for $48 \mathrm{~h}$, weighed again $\left(\mathrm{DW}_{\text {sample }}\right.$ ), and then ground to a fine powder with a ring crusher (CB2200, SODEMI, Aix-en-Provence, France) before elemental analysis. The data were then used to estimate the total dry weight (DW) of each organ. The root mass fraction (RMF) was calculated as the root dry biomass divided by the total tree dry biomass.

\subsection{Leaf area}

During each tree harvest (June 2012, 2013, 2014, and 2015), the crowns of the sampled trees were divided into three equal 
parts; all the leaves from each crown section were collected and weighed $(\mathrm{FW})$. Then, about 20 leaves per crown section were weighed $\left(\mathrm{FW}_{\text {sample }}\right)$ and their area $\left(\mathrm{LA}_{\text {sample }}\right)$ was determined with a leaf area meter (Li-Cor, Li-3000A, Lincoln, Nebraska, USA). The total leaf area (LA) of each crown section was calculated as follows:

$\mathrm{LA}=\mathrm{LA}_{\text {sample }} \times \frac{\mathrm{FW}}{\mathrm{FW}_{\text {sample }}}$

The leaf area of the whole tree was determined as the sum of the areas of each crown section.

\subsection{Elementary analyses}

$\mathrm{N}$ concentrations $(\%)$ in the dry matter were measured with an elemental analyzer (NA-1500, Carlo Erba, Milan, Italy) from 2 to $5 \mathrm{mg}$ of powder from each organ (branches, stem, roots and leaves) or soil samples. $\mathrm{N}$ contents were calculated by multiplying $\mathrm{N}$ concentrations of each organ by its dry weight (DW). $\mathrm{N}$ concentration was calculated for the whole tree as follows:

$\mathrm{N}_{\text {tree }}=\frac{\mathrm{N}_{\text {branches }} \mathrm{DW}_{\text {branches }}+\mathrm{N}_{\text {stem }} \mathrm{DW}_{\text {stem }}+\mathrm{N}_{\text {roots }} \mathrm{DW}_{\text {roots }}+\mathrm{N}_{\text {leaves }} \mathrm{DW}_{\text {leaves }}}{\mathrm{DW}_{\text {branches }}+\mathrm{DW}_{\text {stem }}+\mathrm{DW}_{\text {roots }}+\mathrm{DW}_{\text {leaves }}}$

\subsection{Extrapolation to stand level}

At each harvest, allometric equations relating total biomass as well as root, stem (including branches), and leaf biomass, total leaf area and total $\mathrm{N}$ content of the harvested trees with their height and diameter were established. Power relationships were used. The choice of the most adapted equation was based on the AIC (Akaike Information Criterion) and RMSE (root mean square error) values obtained when equations were adjusted on the datasets. The most relevant model was the one with the lowest AIC and RMSE values. The treatment effect was included in the equation as a dummy variable when the adjustment parameters were improved (lower AIC and RMSE; Table 4). The allometric equations were applied to the 49 trees ( 7 trees in 7 rows) in the central part of each treatment in the two blocks. These zones, preserved from tree harvests, were also used to estimate tree mortality at the end of each growing season.

The estimated values of biomass, leaf area and $\mathrm{N}$ content were used to calculate biomass production per hectare $\left(\mathrm{Mg}_{\mathrm{DW}} \mathrm{ha}^{-1}\right)$, aboveground net primary production (ANPP, $\mathrm{Mg}_{\mathrm{DW}} \mathrm{ha}^{-1} \mathrm{year}^{-1}$ ), leaf area index (LAI, $\mathrm{m}^{2}$ leaves $\mathrm{m}^{-2}$ soil $)$, and tree $\mathrm{N}$ per hectare at stand level ( $n=2$ blocks). The interaction between the two species at stand level was calculated as the relative difference between the value in the mixture and the average values of the two monocultures: $X_{50 A 50 E} / \overline{X_{100 A}, X_{100 E}}-1$. The effect of the mixture on each species was calculated as the relative difference between twice the value for this species in the mixture (to account for a density twice as low for each species in the mixture) and the value of the same species in the monoculture: $2 \times X_{50 \mathrm{~A} 50 \mathrm{E}} / X_{\text {monoculture }}-1$ (relative competition intensity, RCI; Grace 1995).

\subsection{Statistical analyses}

Results were analyzed with the R software (R Core Team 2016). Means were expressed with their standard errors. Statistical tests were considered significant at $* P \leq 0.05$, $* * P \leq 0.01$, or $* * * P \leq 0.001$. At tree level $(n=8)$, data were compared between harvest dates, species, and treatments (i.e., two treatments: pure or mixed) using a three-way ANOVA. At stand level $(n=2)$, data were compared between harvest dates and plot types (i.e., three plot types: two monocultures of each of the two species and one mixture) with a two-way ANOVA. General linear models were used to compare (1) mortality between years, species and treatments; (2) soil $\mathrm{N}$ data between dates (initial vs. final), plot types, and soil horizons; and (3) initial soil texture and composition between plots and soil horizons.

Data availability The datasets generated during and/or analyzed during the current study are available from the corresponding author on reasonable request.

\section{Results}

\subsection{Soil and climate conditions over time}

Soil texture and composition prior to planting did not show any significant gradient on the future stand area that would have resulted in differences between plots. Average values are given in Table 1. Total soil $\mathrm{N}$ decreased linearly with soil depth, irrespective of plot type or date (Fig. 1). No significant effects of the plot type and sampling time (initial vs. final) were observed. Annual total precipitation ranged from 531 to $867 \mathrm{~mm}$, with precipitation during the growing season (May to August) ranging from 202 to $409 \mathrm{~mm}$ (Table 2). When compared to the decennial (2005-2015) rainfall average $(620 \mathrm{~mm})$, years 2011 and 2015 were the driest, while years 2013 and 2014 were the wettest. It is noteworthy that year 2013 was wet during winter and fall, but quite dry during summer. Mean annual temperatures ranged from 10.9 to $12.3{ }^{\circ} \mathrm{C}$. The 2015 growing season was the warmest $\left(18.2{ }^{\circ} \mathrm{C}\right.$ on average between May and August), while the 2014 growing season was the coolest $\left(16.7^{\circ} \mathrm{C}\right)$.

No significant difference was observed among plot types in terms of soil water content (SWC), so average values are presented. SWC at $10-\mathrm{cm}$ depth reached values below $10 \%$ 


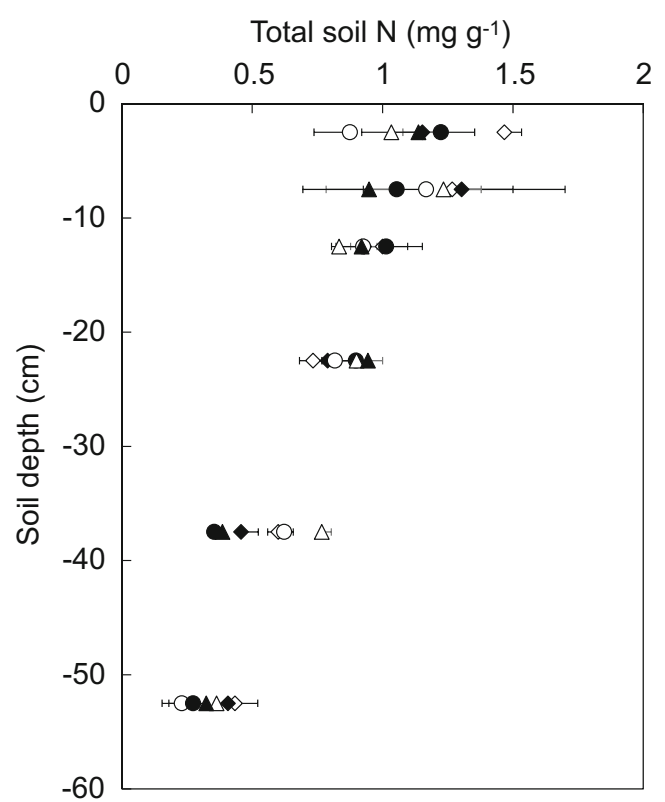

Fig. 1 Soil profiles for total $\mathrm{N}$ in the poplar (circles), black locust (diamonds), and mixed (triangles) plots before planting (open symbols) and 5 years later (closed symbols). Means \pm standard errors, $n=2$. Only soil depth was significant $(* * P \leq 0.001)$

during summers 2012, 2013, and 2015, with the lowest values (5.9\%) observed in July 2015 (Fig. 2). Soil water decreased much less markedly during the growing seasons in 2011 and 2014. The soil was waterlogged (with soil water content values at saturation around 35\%) for almost 7 months (November to May) in 2012-2013, but only for 5 months (December to April) in 2014-2015.

\subsection{Tree mortality over time}

Significant species, year $(P \leq 0.001)$, treatment, and species $\times$ year $(P \leq 0.05)$ effects were observed in terms of tree mortality (Table 3). For both species, tree mortality increased in the mixture in 2013 , reaching $9 \%$ for poplar and $16 \%$ for black locust. From this date on, mortality for black locust in both the pure and mixed treatments drastically increased year after year, reaching $23.5 \%$ in the monoculture and $54 \%$ in the

Table 2 Climatic conditions between 2011 and 2015 in terms of total annual precipitation (TAP), total precipitation during the growing season (May to August, TSP), mean annual temperatures (MAT), and mean temperatures during the growing season (MST)

\begin{tabular}{lllll}
\hline Year & TAP $(\mathrm{mm})$ & TSP $(\mathrm{mm})$ & MAT $\left({ }^{\circ} \mathrm{C}\right)$ & MST $\left({ }^{\circ} \mathrm{C}\right)$ \\
\hline 2011 & 531 & 213 & 12.3 & 17.2 \\
2012 & 705 & 245 & 11.2 & 17.4 \\
2013 & 816 & 226 & 10.9 & 17.1 \\
2014 & 867 & 409 & 12.2 & 16.7 \\
2015 & 609 & 202 & 12.0 & 18.2 \\
\hline
\end{tabular}

mixture at the end of 2015. For poplar, the increase in mortality over time was less marked; however, in 2015, 2 and $12.5 \%$ of the trees were dead in the monoculture and mixed plantations, respectively.

\subsection{Tree height changes over time}

During all five growing seasons, height growth occurred between May and September for both species (Fig. 2). Height growth over time for poplar followed a sigmoid shape, except for 2013 and 2015, during which tree growth was particularly low. No significant difference in stem height was observed between poplar trees in the monoculture and in the mixture. For black locust as well, height growth over time followed a sigmoid shape, but only during the growing seasons of 2011 and 2012. The black locusts in the mixture were taller than the poplars and also taller than the black locusts in the monoculture at the end of the first growing season. However, from 2013 on, the black locusts stagnated and no height growth occurred. Tree heights even decreased with time because regrowth in spring often does not occur from the apical bud for this species. This lack of apical regrowth was more marked in the mixture than in the monoculture. At the end of the experiment, the poplar trees were twice as tall as the trees in the black locust monoculture and almost four times as tall as the black locust trees in the mixed treatment.

\subsection{Biomass production and allocation}

At tree level, significant date and species effects were observed in terms of biomass and root mass fraction (RMF), though no treatment effect was highlighted for these variables (Fig. 3). A significant species by treatment $(\mathrm{S} \times \mathrm{T})$ interaction was observed for biomass production $(P \leq 0.05)$ and tree $\mathrm{N}$ content $(P \leq 0.001)$. Total tree biomass as well as aboveground woody biomass increased almost linearly with time in the two monocultures and for poplar in the mixture. For black locust in the mixture, total and aboveground woody biomass stagnated around 1.5 and $0.8 \mathrm{~kg}$, respectively, from month 28. Tree biomass was almost four times less for black locust in the mixture than in the pure stands. This is reflected by a significant $\mathrm{S} \times \mathrm{T}$ interaction. RMF remained globally stable over time for black locust, while it decreased progressively for poplar; consequently, RMF did not differ between the two species at the beginning of the experiment but was significantly lower for poplar than for black locust at the end.

At the end of the experiment, at stand level, the poplar monoculture was twice as productive as both the black locust monoculture and the mixture (Fig. 4). For black locust in the mixture, a decline in biomass per hectare was observed over time, with negative values of aboveground net primary production (ANPP) in some cases, due to increasing tree mortality. Differences between the two monocultures in terms of leaf 
Fig. 2 Tree stem heights over time in monocultures (white) and mixtures (black) for poplar (circles) and black locust (diamonds) (means \pm standard errors, $n=40$ ) and soil volumetric water content at $10-\mathrm{cm}$ depth (means, $n=8$ ) between 2011 and 2015. At the end of each growing season, different letters indicate significant differences between species and treatments for $P \leq$ 0.05 . Plantation and harvest dates are indicated by arrows
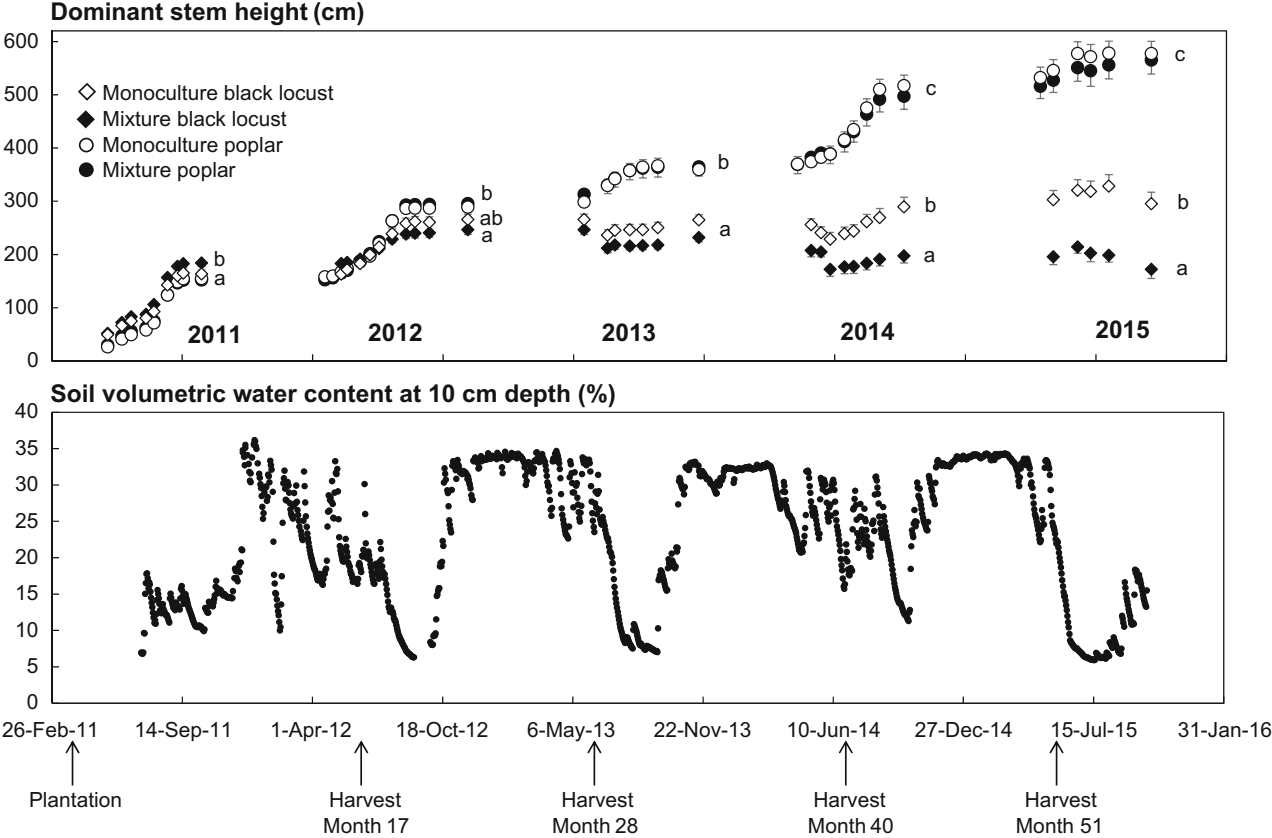

area index (LAI) were less marked than in terms of biomass production per hectare. LAI increase in the mixture was essentially driven by the poplar trees since black locust LAI was close to zero. Interactions between the two species in terms of biomass production and LAI were almost nil at month 17, and then they became more and more negative with time, the mixture being around $40 \%$ less productive than the average values of the two monocultures at month 51 (Fig. 5). The negative interactions at stand level were mostly due to the response of black locust in the mixture: indeed, black locust biomass production and LAI were both almost nil at the end of the experiment.

\subsection{Nitrogen dynamics}

$\mathrm{N}$ content in trees increased with time for both species and treatments (Fig. 3). N content was significantly higher in black locust in the monoculture than in poplar, irrespective of treatment, and then in black locust in the mixture from month 40 onward. At stand level, no significant time effect was observed for $\mathrm{N}$ content per hectare (Fig. 4). $\mathrm{N}$ content was the highest in the black locust monoculture and the lowest in the mixture, the poplar monoculture being intermediate. Interactions between the two species at stand level were null at month 17 and decreased with time to reach -0.7 at month 51 (Fig. 5). For poplar, no interaction effect was observed in the mixture irrespective of date, while for black locust, $\mathrm{N}$ accumulation in the mixture was almost $100 \%$ less than in the monoculture at month 51 .

\section{Discussion}

\subsection{Plantation evolution over time}

After two first promising growing seasons, tree survival and growth in both species was strongly affected by a long period of flooding during the 2013 winter, followed by a dry summer; this combination triggered the slow decline of the plantation. A similar situation occurred again in 2015, with a more severe summer drought resulting in only around 5-10\% volumetric soil water content at a $10-\mathrm{cm}$ depth for two and a half months (mid-June to end August). In spite of the different ecological requirements of the two supposedly complementary species,

Table 3 Tree mortality over time (\%) measured at the end of the growing seasons, from 2011 to 2015 for poplar and black locust, in the monocultures and mixed plantations. Means \pm standard errors, $n=2$

\begin{tabular}{|c|c|c|c|c|c|c|}
\hline & & 2011 & 2012 & 2013 & 2014 & 2015 \\
\hline \multirow[t]{2}{*}{ Poplar } & Monoculture & $1.0 \pm 1.0$ & $1.0 \pm 1.0$ & $2.0 \pm 2.0$ & $2.0 \pm 2.0$ & $2.0 \pm 2.0$ \\
\hline & Mixture & $1.8 \pm 1.8$ & $1.8 \pm 1.8$ & $8.9 \pm 1.8$ & $10.7+3.6$ & $12.5 \pm 5.4$ \\
\hline \multirow[t]{2}{*}{ Black locust } & Monoculture & $0.0 \pm 0.0$ & $1.0 \pm 1.0$ & $6.1 \pm 0.0$ & $21.4 \pm 9.2$ & $23.5 \pm 11.3$ \\
\hline & Mixture & $1.8 \pm 1.8$ & $1.8 \pm 1.8$ & $16.1 \pm 8.9$ & $48.2 \pm 19.7$ & $53.6 \pm 21.4$ \\
\hline
\end{tabular}


Table 4 Allometric relationships established for poplar and black locust trees at ages 17, 28, 40, and 51 months. Number of trees (n), determination coefficients $\left(R^{2}\right)$, and root mean square errors (RMSE) are also indicated. When data did not differ between treatments, trees from the monoculture (Mono) and mixtures (Mix) were combined for the establishment of the relationships. $D v=$ virtual diameter (mm); $H=$ stem height $(\mathrm{cm})$

\begin{tabular}{|c|c|c|c|c|c|c|c|}
\hline & Species & Treatment & $\begin{array}{l}\text { Age } \\
\text { (months) }\end{array}$ & Equation & $n$ & $R^{2}$ & RMSE \\
\hline \multirow[t]{9}{*}{ Aboveground dry biomass (g) } & \multirow[t]{4}{*}{ Poplar } & Mix + mono & 17 & $40.86 D v-1.859 H-224.58$ & 16 & 0.98 & 29.36 \\
\hline & & Mix + mono & 28 & $0.002733 D v^{2} H+401.6$ & 16 & 0.85 & 289.4 \\
\hline & & Mix + mono & 40 & $0.3764 D v^{2.3696}$ & 16 & 0.92 & 489.5 \\
\hline & & Mix + mono & 51 & $225.154 \mathrm{Dv}-7.111 H-2348.787$ & 16 & 0.98 & 550.7 \\
\hline & \multirow[t]{5}{*}{ Black locust } & Mix + mono & 17 & $-35.229 \mathrm{Dv}+7.154 \mathrm{H}-278.849$ & 16 & 0.70 & 130.9 \\
\hline & & Mix + mono & 28 & $0.006212 D v^{2} H+92.3$ & 15 & 0.85 & 298.4 \\
\hline & & Mono & 40 & $12.392 D v+1.474$ & 8 & 0.82 & 451.5 \\
\hline & & Mix & 40 & $22.933 D v+1.149$ & 8 & & \\
\hline & & Mix + mono & 51 & $150.46 D v+3.342 H-3129.105$ & 16 & 0.82 & 1136.6 \\
\hline \multirow[t]{9}{*}{ Belowground dry biomass (g) } & \multirow[t]{4}{*}{ Poplar } & Mix + mono & 17 & $6.976 D v-0.589 H+27.873$ & 16 & 0.97 & 4.53 \\
\hline & & Mix + mono & 28 & $0.0005875 D v^{2} H+123.5$ & 15 & 0.74 & 93.33 \\
\hline & & Mix + mono & 40 & $0.0008378 D^{2} H+212.6$ & 16 & 0.72 & 220.7 \\
\hline & & Mix + mono & 51 & $60.447 D v+3.681 H-51.487$ & 16 & 0.97 & 156.0 \\
\hline & \multirow[t]{5}{*}{ Black locust } & Mix + mono & 17 & $-25.434 D v+2.886 H+73.571$ & 16 & 0.68 & 46.03 \\
\hline & & Mix + mono & 28 & $0.002498 D^{2} H+170.5$ & 14 & 0.77 & 172.4 \\
\hline & & Mono & 40 & $7.1335 D v^{1.4746}$ & 8 & 0.82 & 171.8 \\
\hline & & Mix & 40 & $37.8555 D v^{0.7618}$ & 8 & & \\
\hline & & Mix + mono & 51 & $39.07 D v+3.121 H-1296.275$ & 16 & 0.89 & 284.8 \\
\hline \multirow[t]{9}{*}{ Woody dry biomass (g) } & \multirow[t]{4}{*}{ Poplar } & Mix + mono & 17 & $39.95 \mathrm{Dv}-2.476 \mathrm{H}-116.456$ & 16 & 0.95 & 34.70 \\
\hline & & Mix + mono & 28 & $0.002096 D v^{2} H+307.3$ & 16 & 0.88 & 201 \\
\hline & & Mix + mono & 40 & $0.3328 D v^{2.3359}$ & 16 & & \\
\hline & & Mix + mono & 51 & $187.343 D v-5.754 H-2050.765$ & 16 & 0.97 & 527.4 \\
\hline & \multirow[t]{5}{*}{ Black locust } & Mix + mono & 17 & $-44.106 D v+7.064 H-94.291$ & 16 & 0.66 & 130.7 \\
\hline & & Mix + mono & 28 & $0.004772 D v^{2} H+112.4$ & 15 & 0.89 & 186 \\
\hline & & Mono & 40 & $5.462 D v^{1.642}$ & 8 & 0.90 & 248.5 \\
\hline & & Mix & 40 & $16.7 D v^{1.226}$ & 8 & & \\
\hline & & Mix + mono & 51 & $138.704 D v+1.43 H-2596.573$ & 16 & 0.83 & 931.6 \\
\hline \multirow[t]{10}{*}{ Leaf area $\left(\mathrm{cm}^{2}\right)$} & \multirow[t]{5}{*}{ Poplar } & Mix + mono & 17 & $919.397 D v+2.807 H-8271.516$ & 16 & 0.97 & 1310 \\
\hline & & Mix + mono & 28 & $0.08214 D v^{2} H+11,190$ & 15 & 0.90 & 6471 \\
\hline & & Mono & 40 & $20.013 D v^{2.158}$ & 8 & 0.91 & 11,971 \\
\hline & & Mix & 40 & $404.956 D v^{1.355}$ & 8 & & \\
\hline & & Mix + mono & 51 & $4527.423 \mathrm{Dv}-176.623 \mathrm{H}-37,990.959$ & 16 & 0.98 & 11,296 \\
\hline & \multirow[t]{5}{*}{ Black locust } & Mix + mono & 17 & $-1499.256 D v+343.852 H-16,597.968$ & 16 & 0.65 & 7264 \\
\hline & & Mix + mono & 28 & $0.373 D^{3.7472}$ & 15 & 0.93 & 8678 \\
\hline & & Mono & 40 & $7.4951 D v^{2.5952}$ & 8 & 0.72 & 23,956 \\
\hline & & Mix & 40 & $1157.2757 D v^{0.6673}$ & 8 & & \\
\hline & & Mix + mono & 51 & $5841.87 D v+25.658 H-115,491.008$ & 16 & 0.65 & 43,385 \\
\hline \multirow[t]{9}{*}{$\mathrm{N}$ total $(\mathrm{g})$} & \multirow[t]{4}{*}{ Poplar } & Mix + mono & 17 & $0.314 D v-0.006 H-2.179$ & 16 & 0.95 & 1.555 \\
\hline & & Mix + mono & 28 & $0.00002824 D v^{2} H+5.709$ & 16 & 0.85 & 3.126 \\
\hline & & Mix + mono & 40 & $0.00002071 D v^{2} H+5.356$ & 16 & 0.76 & 6.014 \\
\hline & & Mix + mono & 51 & $0.475 D v-0.023 H+0.084$ & 16 & 0.98 & 0.959 \\
\hline & \multirow[t]{5}{*}{ Black locust } & Mix + mono & 17 & $-0.738 D v+0.151 H-6.654$ & 16 & 0.72 & 2.662 \\
\hline & & Mix + mono & 28 & $0.0000481 D v^{2} H^{1.10269}$ & 15 & 0.82 & 5.461 \\
\hline & & Mono & 40 & $1.0467 D v^{0.6915}$ & 8 & 0.75 & 9.612 \\
\hline & & Mix & 40 & $0.6915 D v^{0.929}$ & 8 & & \\
\hline & & Mix + mono & 51 & $1.223 D v+0.075 H-32.887$ & 16 & 0.78 & 1.281 \\
\hline
\end{tabular}



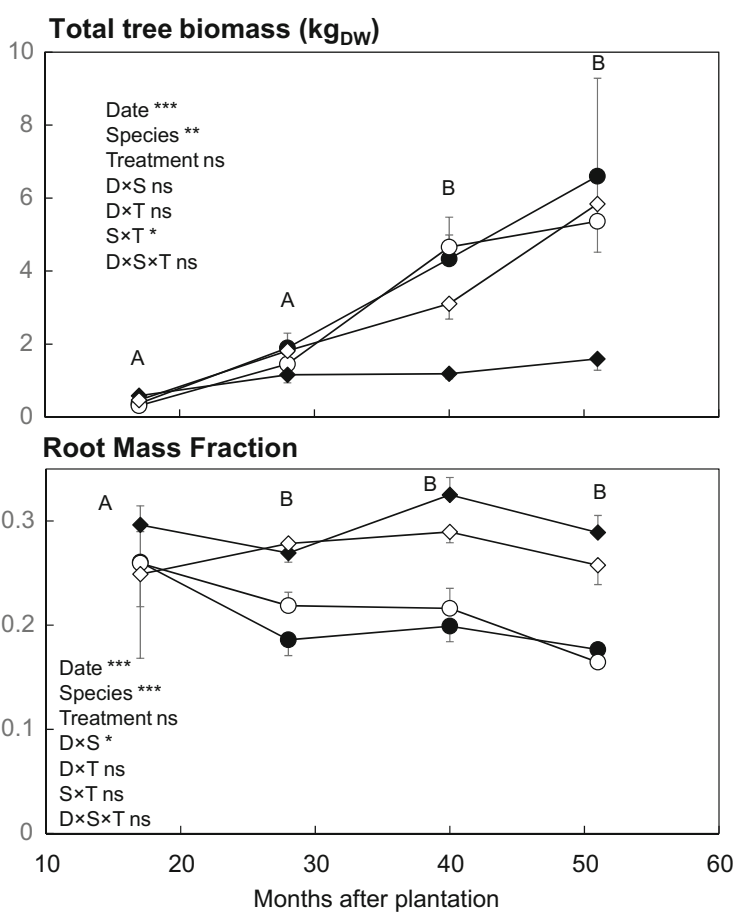

Fig. 3 Total tree biomass, aboveground woody biomass per tree, root mass fraction, and tree nitrogen content over time for poplar (circles) and black locust (diamonds) in monocultures (white) and in mixtures (black) (means \pm standard errors, $n=8$ ). The effects of date (D), species
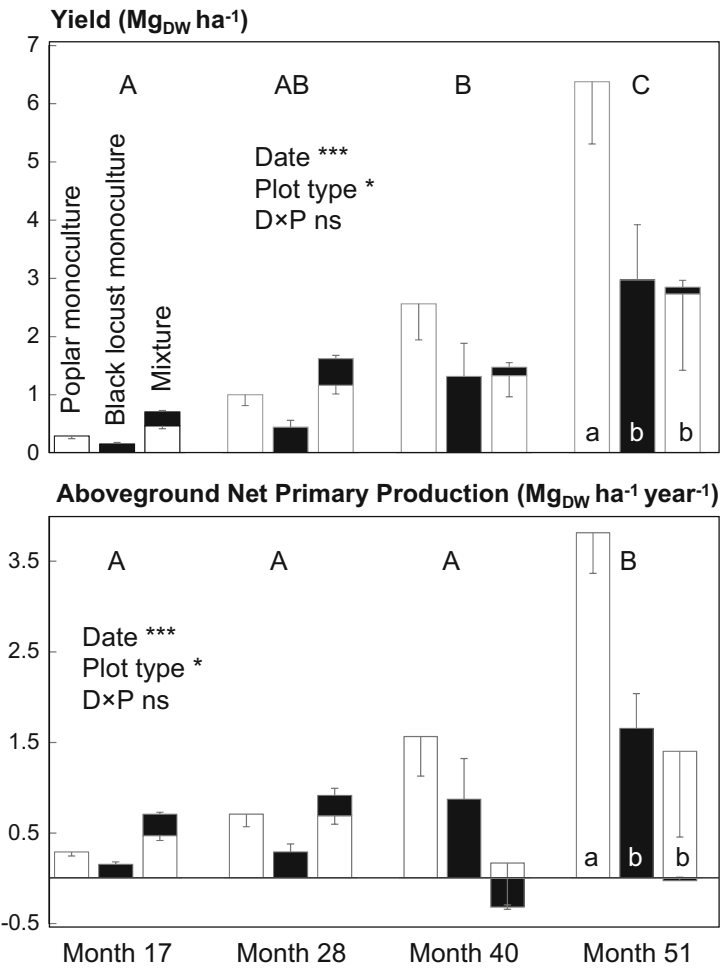

Fig. 4 Biomass production per hectare, aboveground net primary production, leaf area index, and tree nitrogen per hectare over time for poplar (white) and black locust (black) in monocultures and in mixtures (means \pm standard errors, $n=2$ ). The effects of date (D), plot type (P: poplar monoculture, black locust monoculture, and two-species mixture),
Aboveground woody biomass per tree $\left(\mathrm{kg}_{\mathrm{pw}}\right)$
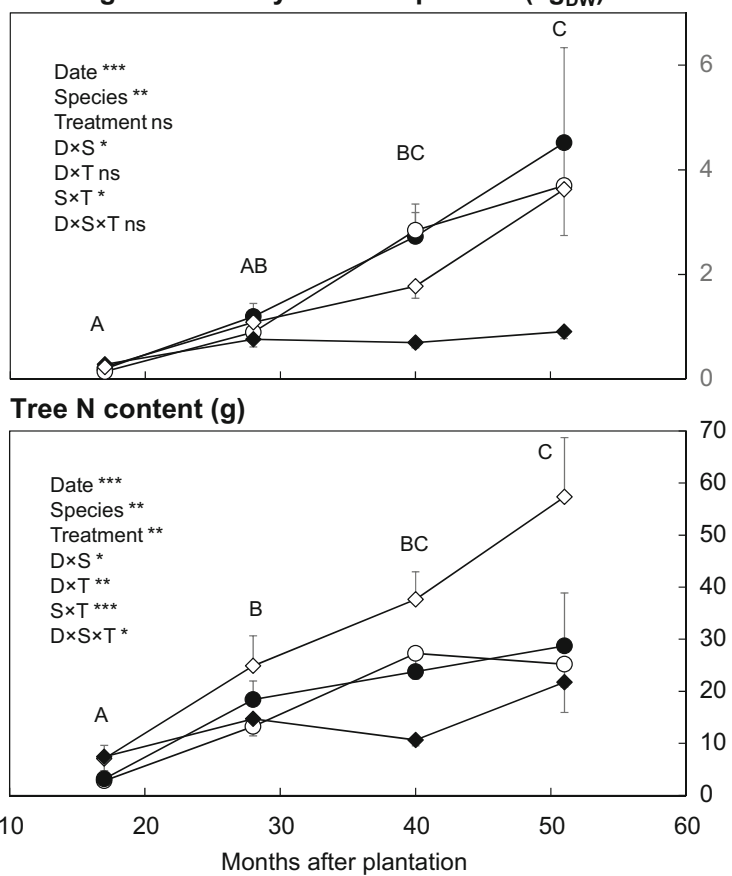

$(\mathrm{S})$, and treatment $(\mathrm{T})$ and their interactions are indicated for $* P \leq 0.05$, $* * P \leq 0.01$, and $* * * P \leq 0.001$; ns for non-significant. Different letters indicate significant differences among dates

Leaf Area Index $\left(\mathrm{m}^{2} \mathrm{~m}^{-2}\right)$

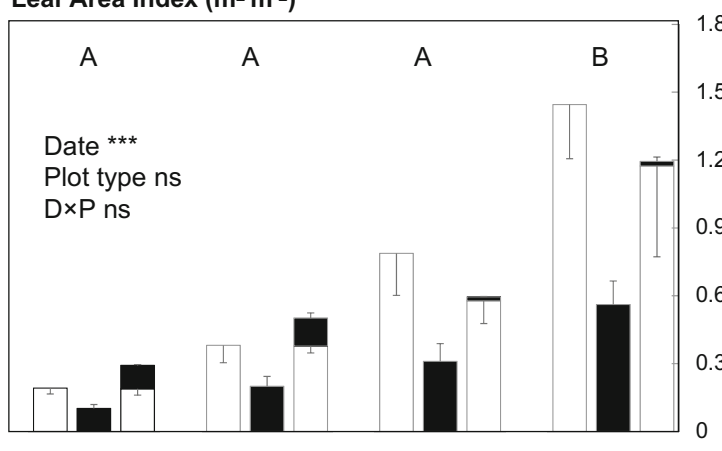

Nitrogen (kg ha-1)

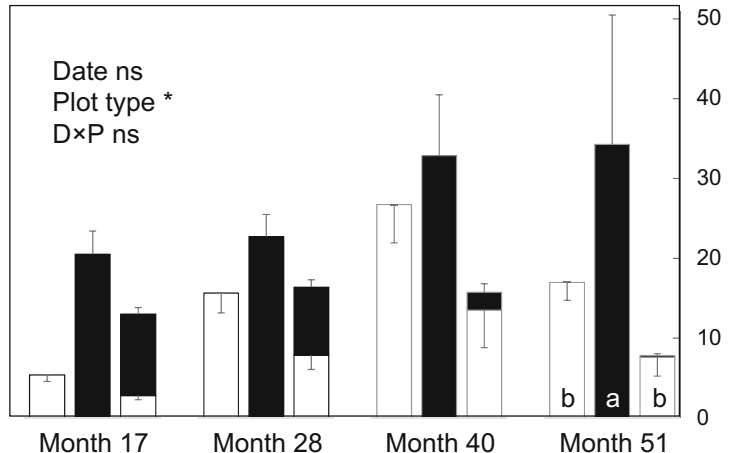

and their interaction are indicated for $* P \leq 0.05$ and $* * * P \leq 0.001$; ns for non-significant. Different capital letters indicate significant differences among dates. Different small letters indicate significant differences among the three plot types 

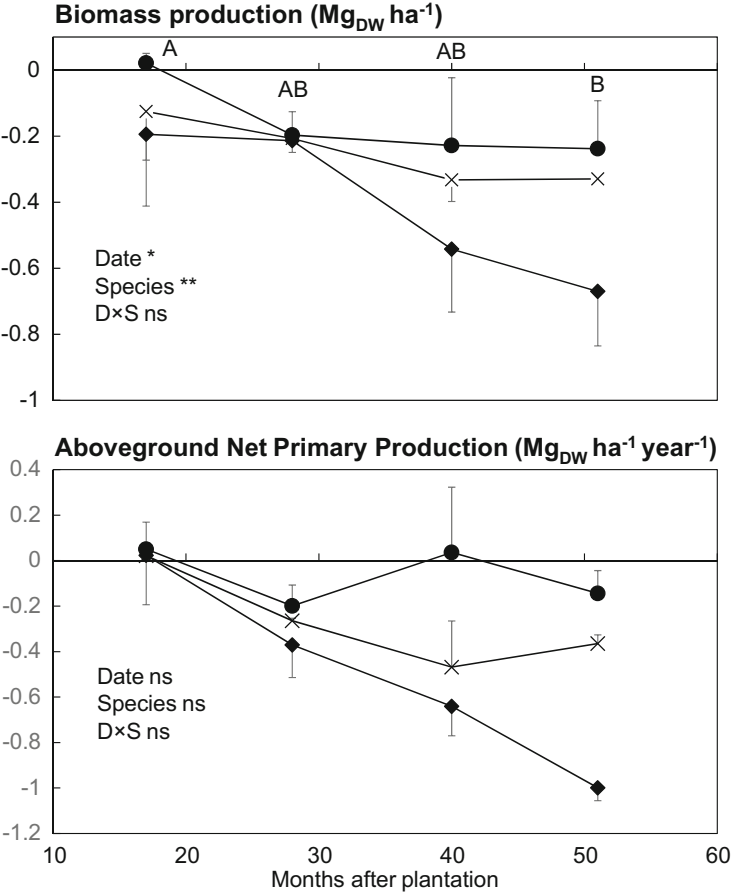

Fig. 5 Interactions between the two species at stand level (crosses) and effects of the mixture on each species (circles for poplar, diamonds for black locust) over time in terms of biomass production per hectare, aboveground net primary production, leaf area index, and tree nitrogen

the pedoclimatic conditions at our site resulted in stressful conditions for both of them, poplar being affected by severe droughts, and black locust by long-term flooding. While poplar is globally sensitive to water shortage, black locust has been shown to better tolerate drought episodes but to withstand flooding less well (Grunewald et al. 2007; Grunewald et al. 2009; Blanco-Canqui 2016). Besides affecting tree growth, the flooding probably also affected black locust $\mathrm{N}_{2}$ fixation. For alder, it has been shown that fall flooding is less damaging than spring and summer flooding in terms of tree mortality, yet symbiotic $\mathrm{N}_{2}$ fixation is totally stopped with no subsequent recovery irrespective of the period of the year flooding occurs (Kaelke and Dawson 2003). In our case, the decline was more severe in the mixture than in the monoculture - in terms of mortality for poplar and in terms of both mortality and biomass production for black locust. This indicates that interspecific competition in the mixture negatively affected the growth and survival of both species. This decline was due to the bad performance of both species as compared to their respective monocultures, but was particularly driven by black locust, with virtually no production occurring after five growing seasons. The non-fixing species must exert a weaker competition on the fixing species than does its own intraspecific competition for the mixture to work. Piotto (2008) carried out a meta-analysis on tree mixtures and showed that, most often, the mixture is not advantageous for the fixing species because it does not benefit from any effect
Leaf Area Index $\left(\mathrm{m}^{2} \mathrm{~m}^{-2}\right)$
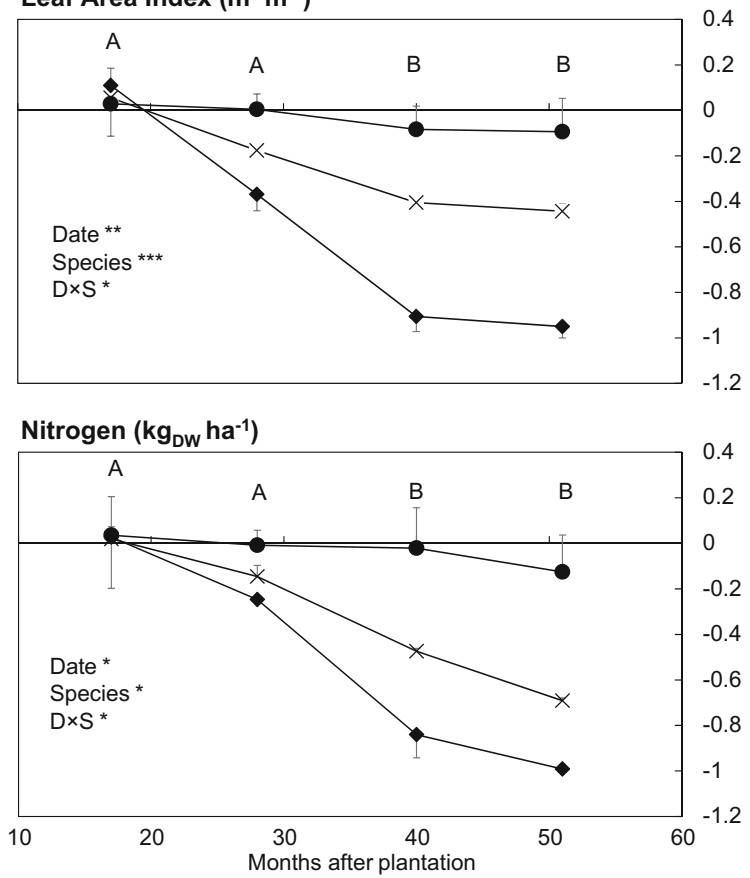

per hectare (means \pm standard errors, $n=2$ ). The effects of date (D), species (S), and their interaction are indicated for $* P \leq 0.05, * * P \leq 0.01$, and $* * * P \leq 0.001$; ns for non-significant. Different letters indicate significant differences among dates

of facilitation or decreased competition on the part of the nonfixing species.

\subsection{Possible reasons for the poor performance of the mixture as compared to monocultures}

In spite of a demonstrated and significant $\mathrm{N}_{2}$ fixation potential (Danso et al. 1995; Marron et al. 2018), black locust is almost absent from the scientific literature dealing with introducing woody $\mathrm{N}_{2}$-fixing species into tree plantations. This lack of research could indicate that (1) using black locust in mixed plantations has been underestimated in research and development, or (2) black locust is difficult to manage because of its unpredictable growth and colonization habits and difficult to manipulate due to its potentially harmful thorns. The success of mixed plantations, defined as the percentage of superiority in terms of biomass production in the mixture as compared to the most productive of the two monocultures, is also extremely variable, ranging from $57 \%$ less productive (Moukoumi et al. 2012) to $153 \%$ more productive (DeBell et al. 1985). In our study, from age 28 months on, the mixture was 22 to $52 \%$ less productive than the best performing monoculture, depending on the age of the plantation. These values clearly fall among the lowest values reported in the literature.

As stressed by Forrester et al. (2005, 2006a), the understanding of the processes and interactions occurring in mixed stands is crucial to maximizing the probability of success. 
These authors identified three major factors contributing to the success of mixed tree plantations: (1) compatibility between height growth rates of the two species to ensure that the less shade-tolerant species will not be overtopped by the more shade-tolerant species, (2) adequate selection of $\mathrm{N}_{2}$-fixing species based on their ability to cycle nutrients and to fix $\mathrm{N}_{2}$, and (3) appropriate site selection.

(1) In our mixed plantation, the canopy was not yet closed at the end of the experiment ( 5 years) because of the slow development of the trees; the decline cannot be attributed to this factor. To optimize the effectiveness of facilitation and competition reduction in mixtures, the plantation design is of importance. For instance, alternating trees of the two species in the same rows has been shown to be slightly more efficient than alternating rows (Zhang 2003). However, in practical terms, a plantation design with trees of different species side by side in the same row could be problematic if harvest timings differ because of variable growth rates. In terms of species proportions in the mixture, one third of fixing species resulted in the best performances in some cases (Xiao et al. 1999a), while two thirds were the best option in other cases (Binkley et al. 2003), and 50-50 remaining the best compromise in many situations (Bi and Turvey 1994; DeBell et al. 1997; Zhang 2003). Planting density (Samraj et al. 1977) and subsequently, harvest age (Bauhus et al. 2000) must also be balanced to favor positive interactions. In any case, trees must be harvested before competition overrides the positive interactions; the most positive mixture effects are not necessarily observed at the highest planting densities (Samraj et al. 1977). In our case, the decline of the plantation did not allow us to complete a rotation, but our high planting density could have stimulated belowground interspecific competition in the mixture.

(2) In our experiment, a significant $\mathrm{N}_{2}$ fixation by the black locust trees has been demonstrated using isotopic methods (Marron et al. 2018). We showed that up to three quarters of black locust $\mathrm{N}$ came from symbiotic fixation. Therefore, the decline of the plantation cannot be attributed to a lack of $\mathrm{N}_{2}$ fixation by the black locust trees. Nevertheless, because of the limited growth of the black locust trees, the total fixed $\mathrm{N}_{2}$ represented low quantities at the stand level (i.e., values at the end of 2013, before the high mortality increase, were 23.5 and $17.7 \mathrm{~kg} \mathrm{~N} \mathrm{ha}^{-1}$ in the black locust monoculture and in the mixture, respectively; Marron et al. 2018, unpublished data). In the literature, the dependence on symbiotic $\mathrm{N}_{2}$ fixation has been extensively described in various woody perennials, accounting for 14 to $100 \%$ of the tree $\mathrm{N}$ contents (see Chalk et al. (2016a) and Chalk et al. (2016b) for reviews), and our fixation rates (up to $76 \%$ of the $\mathrm{N}$ in the black locust trees came from the atmosphere; Marron et al. 2018) are among the highest rates found in the literature. However, a given woody $\mathrm{N}_{2}$-fixing species could be very efficient in stimulating biomass production in a mixture under certain specific conditions (e.g., Leucaena leucocephala in Parrotta et al. 1996) or could, on the contrary, result in a lower biomass production under different conditions in other studies (e.g., as in Austin et al. 1997 for the same Leucaena species). This stresses the importance of the third factor: site selection.

(3) Several studies have shown that biomass production in mixed plantations will be greater than monocultures when soil $\mathrm{N}$ is present in limited quantities (Binkley 1983; Forrester et al. 2006b; Bouillet et al. 2013; Epron et al. 2013). In all these studies, mixed plantations were more productive (i.e., more successful) than monocultures under conditions where soil $\mathrm{N}$ was present in low quantities. It has been hypothesized that facilitation and competition reduction between tree species are more prevalent in sites with low initial nutrient availability, provided that the interactions between species lead to an increase in resource availability, acquisition and efficiency of use (Forrester 2014). Boyden et al. (2005) state that the important role of soil resource availability in moderating both the intensity and nature of tree interactions implies that competition and facilitation studies need to consider a wide range of conditions to be generalizable. In our case, $\mathrm{N}$ may not have been a limiting resource, at least at the beginning of the experiment, and this could explain why no facilitation interactions were needed. However, it does not explain the slower growth and lower survival rate of the two species in the mixture.

In our study, the effect of adverse climate conditions exacerbated interspecific competition in the mixture, resulting in lower tree growth and higher mortality than the monocultures. The mechanisms responsible for this effect are not known and would require further investigations, notably to quantify belowground interactions.

\section{Conclusion}

The high mortality and low biomass production observed in our monocultures compared to the values commonly reported in the literature (e.g., Bastien et al. 2015 and Rédei et al. 2011; with the same poplar clone and black locust provenance, under marginal conditions) highlight the fact that growth conditions were far from optimal at our study site for both species. The negative effects of these adverse conditions were exacerbated in the mixture, showing that negative interactions between species were preponderant. Understanding how 
facilitation and competition respond to pedoclimate conditions is crucial to anticipate whether mixture plantations will be a success, i.e., more productive than monocultures.

Acknowledgements We are particularly grateful to Erwin Dallé for his active contribution to data acquisition in the field and for sample and dataset preparation. We also thank the numerous colleagues and students, as well as the GBFOr Experimental Unit in Orléans (UE 0995), for their help during harvesting.

Funding information Financial support was provided by the Intens\&fix project (ANR-2010-STRA-004-03). The experimental site is part of the SOERE F-ORE-T network supported by GIP ECOFOR, AllEnvi, and AnaEE France. The UMR Silva is supported by the Laboratory of Excellence ARBRE (ANR-11-LABX-0002-01).

\section{References}

Austin MT, Brewbaker JL, Wheeler R, Fownes JH (1997) Short-rotation biomass trial of mixed and pure stands of nitrogen-fixing trees and Eucalyptus grandis. Aust For 60:161-168. https://doi.org/10.1080/ 00049158.1997.10676138

Bastien JC, Berthelot A, Brignolas F, Marron N, Maury S, Bodineau G, Gauvin J, Toillon J, Dallé E, Delaunay A, Charnet F, Maine P, Merzeau D (2015) Augmenter le niveau de production de biomasse des cultures ligneuses. Principaux enseignements du projet SYLVABIOM. Revue Forestière Française 67:249-262

Bauhus J, Khanna PK, Menden N (2000) Aboveground and belowground interactions in mixed plantations of Eucalyptus globulus and Acacia mearnsii. Can J For Res 30:1886-1894. https://doi.org/10.1139/ $\mathrm{x} 00-141$

Bi HQ, Turvey ND (1994) Inter-specific competition between seedlings of Pinus radiata, Eucalyptus regnans and Acacia melanoxylon. Aust J Bot 42:61-70. https://doi.org/10.1071/BT9940061

Binkley D (1983) Ecosystem production in Douglas-fir plantations - interaction of red alder and site fertility. Forest Ecol Manag 5:215227. https://doi.org/10.1016/0378-1127(83)90073-7

Binkley D, Sollins P, Bell R, Sachs D, Myrold D (1992) Biogeochemistry of adjacent conifer and alder-conifer stands. Ecology 73:20222033. https://doi.org/10.2307/1941452

Binkley D, Senock R, Bird S, Cole TG (2003) Twenty years of stand development in pure and mixed stands of Eucalyptus saligna and nitrogen-fixing Facaltaria moluccana. Forest Ecol Manag 182:93102. https://doi.org/10.1016/S0378-1127(03)00028-8

Blanco-Canqui H (2016) Growing dedicated energy crops on marginal lands and ecosystem services. Soil Sci Soc Am J 80:845-858. https://doi.org/10.2136/sssaj2016.03.0080

Bouillet JP, Laclau JP, Goncalves JLD, Voigtlaender M, Gava JL, Leite FP, Hakamada R, Mareschal L, Mabiala A, Tardy F, Levillain J, Deleporte P, Epron D, Nouvellon Y (2013) Eucalyptus and Acacia tree growth over entire rotation in single- and mixed-species plantations across five sites in Brazil and Congo. Forest Ecol Manag 301: 89-101. https://doi.org/10.1016/j.foreco.2012.09.019

Boyden S, Binkley D, Senock R (2005) Competition and facilitation between Eucalyptus and nitrogen-fixing Falcataria in relation to soil fertility. Ecology 86:992-1001. https://doi.org/10.1890/04-0430

Chalk PM, Inacio CT, Balieiro FC, Rouws JRC (2016a) Do techniques based on ${ }^{15} \mathrm{~N}$ enrichment and ${ }^{15} \mathrm{~N}$ natural abundance give consistent estimates of the symbiotic dependence of $\mathrm{N}_{2}$-fixing plants? Plant Soil 399:415-426. https://doi.org/10.1007/s11104-015-2689-9

Chalk PM, Lam SK, Chen DL (2016b) ${ }^{15} \mathrm{~N}$ methodologies for quantifying the response of $\mathrm{N}_{2}$-fixing associations to elevated $\mathrm{CO}_{2}$ : a review. Sci Total Environ 571:624-632. https://doi.org/10.1016/j.scitotenv. 2016.07.030
Core Team R (2016) R: a language and environment for statistical computing. R Foundation for Statistical Computing, Vienna

Danso SKA, Zapata F, Awonaike KO (1995) Measurement of biological $\mathrm{N}_{2}$ fixation in field-grown Robinia pseudoacacia L. Soil Biol Biochem 27:415-419. https://doi.org/10.1016/0038-0717(95) 98612-R

DeBell DS, Whitesell CD, Schubert TH (1985) Mixed plantations of Eucalyptus and leguminous trees enhance biomass production. USDA For Serv Res P PSW-175

DeBell DS, Cole TG, Whitesell CD (1997) Growth, development, and yield in pure and mixed stands of Eucalyptus and Albizia. For Sci 43:286-298

Drénou C (2006) Les racines, face cachée des arbres

Epron D, Nouvellon Y, Mareschal L, Moreira RME, Koutika LS, Geneste B, Delgado-Rojas JS, Laclau JP, Sola G, Goncalves JLD, Bouillet JP (2013) Partitioning of net primary production in Eucalyptus and Acacia stands and in mixed-species plantations: two case-studies in contrasting tropical environments. Forest Ecol Manag 301:102111. https://doi.org/10.1016/j.foreco.2012.10.034

Forrester DI (2014) The spatial and temporal dynamics of species interactions in mixed-species forests: from pattern to process. Forest Ecol Manag 312:282-292. https://doi.org/10.1016/j.foreco.2013.10.003

Forrester DI, Bauhus H, Cowie AL (2005) On the success and failure of mixed-species tree plantations: lessons learned from a model system of Eucalyptus globulus and Acacia mearnsii. Forest Ecol Manag 209:147-155. https://doi.org/10.1016/j.foreco.2005.01.012

Forrester DI, Bauhus J, Cowie AL, Vanclay JK (2006a) Mixed-species plantations of Eucalyptus with nitrogen-fixing trees: a review. Forest Ecol Manag 233:211-230. https://doi.org/10.1016/j.foreco.2006.05. 012

Forrester DI, Bauhus J, Cowie AL (2006b) Carbon allocation in a mixedspecies plantation of Eucalyptus globulus and Acacia mearnsii. Forest Ecol Manag 233:275-284. https://doi.org/10.1016/j.foreco. 2006.05.018

Grace JB (1995) On the measurement of plant competition intensity. Ecology 76:305-308. https://doi.org/10.2307/1940651

Grunewald H, Brandt BKV, Schneider BU, Bens O, Kendzia G, Huttl RF (2007) Agroforestry systems for the production of woody biomass for energy transformation purposes. Ecol Eng 29:319-328. https:// doi.org/10.1016/j.ecoleng.2006.09.012

Grunewald H, Bohm C, Quinkenstein A, Grundmann P, Eberts J, von Wuhlisch G (2009) Robinia pseudoacacia L.: a lesser known tree species for biomass production. Bioenerg Res 2:123-133. https:// doi.org/10.1007/s12155-009-9038-x

Kaelke CM, Dawson JO (2003) Seasonal flooding regimes influence survival, nitrogen fixation, and the partitioning of nitrogen and biomass in Alnus incana ssp rugosa. Plant Soil 254:167-177. https:// doi.org/10.1023/A:1024903912325

Koupar SAM, Hosseini SM, Tabari M, Modirrahmati A, Golchin A, Rad FH (2011) Effects of pure and mixed plantations of Populus deltoides with Alnus glotinosa on growth and soil properties: a case study of Foman region, Iran. Afr J Agric Res 6:5261-5265

Le Tacon F, Bouchard D, Garbaye J (1988) Augmentation de la croissance intiale du frêne (Fraxinus excelsior L.) par épandage de boues de station d'épuration urbaine et plantation intercalaire d'aulne blanc (Alnus incana (L.) Moench.) Revue Forestière Française:117125. https://doi.org/10.4267/2042/25871

Levillain J, M'Bou AT, Deleporte P, Saint-Andre L, Jourdan C (2011) Is the simple auger coring method reliable for below-ground standing biomass estimation in Eucalyptus forest plantations? Ann Bot 108: 221-230. https://doi.org/10.1093/aob/mcr102

Mantovani D, Veste M, Boldt-Burisch K, Fritsch S, Koning LA, Freese D (2015) Carbon allocation, nodulation, and biological nitrogen fixation of black locust (Robinia pseudoacacia L.) under soil water limitation. Ann For Res 58:259-274 
Marron N, Gana C, Gérant D, Maillard P, Priault P, Epron D (2018) Estimating symbiotic $\mathrm{N}_{2}$ fixation in Robinia pseudoacacia. J Plant Nutr Soil Sci In press

Moraes de Jesus R, Brouard JS (1989) Eucalyptus - Leucaena mixture experiment. I. Growth and yield. Int Tree Crop J 5:257-269. https:// doi.org/10.1080/01435698.1989.9752861

Moukoumi J, Farrell RE, Van Rees KJC, Hynes RK, Belanger N (2012) Intercropping Caragana arborescens with Salix miyabeana to satisfy nitrogen demand and maximize growth. Bioenerg Res 5:719732. https://doi.org/10.1007/s12155-012-9181-7

Parrotta JA, Baker DD, Fried M (1996) Changes in dinitrogen fixation in maturing stands of Casuarina equisetifolia and Leucaena leucocephala. Can J For Res 26:1684-1691. https://doi.org/10. 1139/x26-190

Piotto D (2008) A meta-analysis comparing tree growth in monocultures and mixed plantations. For Ecol Manag 255:781-786. https://doi. org/10.1016/j.foreco.2007.09.065

Rédei K, Csiha I, Keserü Z (2011) Black locust (Robinia pseudoacacia L.) short-rotation crops under marginal conditions. Acta Silv Lignaria Hung 7:125-132

Samraj P, Chinnamani S, Haldorai B (1977) Natural versus man-made forest of Nilgiris with special reference to run-off, soil loss and productivity. Indian For 103:460-465
Tarrant RF, Trappe JM (1971) Role of Alnus in improving forest environment. Plant Soil Special Volume 35:335-348. https://doi.org/10. 1007/BF02661862

Teissier du Cros E, Jung G, Bariteau M (1984) Alder-Frankia interaction and alder - poplar association for biomass production. Plant Soil 78:235-243. https://doi.org/10.1007/BF02277854

Toillon J, Fichot R, Dalle E, Berthelot A, Brignolas F, Marron N (2013) Planting density affects growth and water-use efficiency depending on site in Populus deltoides x P. nigra. For Ecol Manag 304:345354. https://doi.org/10.1016/j.foreco.2013.05.017

Vandermeer JH (1989) The ecology of intercropping. Cambridge University Press, Cambridge. https://doi.org/10.1017/ CBO9780511623523

Xiao W, Wang S, Chen X, Lu J, Wu G, Xiao L, Chen Y, Kang S, Chen J, Lin J, Zhou Q, Zhang X (1999) Biomass of eucalypts and Acacia crassicarpa mixed forest and its influence to soil. For Sci Technol $15: 8-15$

Zhang N (2003) Experiment on eucalypt U6 clone intercropping with Acacia crassicarpa. Master's Thesis Research Institute of Tropical Forestry and Leizhou Forest Bureau (in Mandarin) 